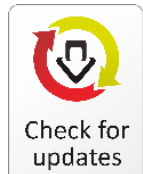

updates

Article Type: Research Paper

\title{
The Impact of Foreign Investor Ownership Level on Agency Problems of Manufacturing Companies in Indonesia
}

\author{
Ahmad Cahyo Nugroho*, Dedi Febrianto, Avia Enggar Tyasti, \\ Christian Kuswibowo
}

\begin{abstract}
:
Research aims: Investment plays an essential role in the business growth of a company and the economy to develop more broadly. The role makes each institution implement investment targets and takes all actions to support the realization of investment targets. This study proves that foreign investors can change the investment behavior of companies and the interaction among decisions.

Design/Methodology/Approach: The study used a dynamic panel data analysis method based on the financial statements of 100 manufacturing companies listed on the Indonesia Stock Exchange (IDX).

Research findings: Increasing foreign ownership does not always reduce agency problems. The analysis shows that the level of share ownership of foreign investors changed the company's investment behavior. These results indicate that there are different agency problems in different ownership level of foreign investors.

Theoretical contribution/Originality: This study provides a new perspective and empirical evidence that the relationship between agency problems and foreign share ownership is not static.

Practitioner/Policy implication: This study analyzes the effect of the composition of foreign investors on the allocation of corporate funds by investigating capital asset investment and current asset investment interactions. This research contributes to the firm's ability to control its own goals.

Research limitation/Implication: This research has not considered the company's risk characteristics related to the type of industry. For further research development, it is necessary to consider the company's risk characteristics to enhance the analysis.
\end{abstract}

Keywords: Agency Problem; Foreign Investor; Investment behavior; Indonesia

\section{Introduction}

This research provides a new perspective of agency theory implementation in explaining investment decisions in conditions in emerging and ineffective markets such as Indonesia. Investment plays an essential role in a company's business growth and economy. The magnitude of an investment role makes each institution implement investment targets and does any actions to support the realization of 
investment targets. Investment decisions can impact the company's value (Karuna, 2007, Laksmana \& Yang, 2015). The implementation of investment is significant for the company's achievement and sustainability in the future, so the impact obtained depends on predictions and decisions made by the company's managers. Investment is closely related to agency theory that founded on seven underlying assumptions: personal interests, conflicting goals, bounded rationality, information asymmetry, efficiency advantages, risk aversion, and information as a commodity (Eisenhardt, 1989; Haaskjold, Andersen, Lædre, \& Aarseth, 2019).

When companies allocate more funds for investment in current assets to increase the sales and value of the company, the operational risk of the company will automatically increase (Michalski, 2008). In operational activities, when the company decides to invest in current assets to increase sales, the company sacrifices the opportunity to invest in fixed assets to increase the company's operational capacity in capturing opportunities to increase sales in the future (Cheatham, 1989). When a company gets an investment opportunity, there will be agency problems due to the difference in perspective between management and the owner of the company in interpreting opportunities and risks in making investment decisions.

The existence of foreign investment in companies in Indonesia is an inevitable phenomenon in economic globalization. Investment decisions are inseparable from the role of corporate governance (Guariglia \& Yang, 2016). In the study of Chen, Sun, and Xu (2016) on the relationship between the level and type of ownership with the allocation of investment funds, the type and level of ownership of a company have an essential role in determining the investment behavior of a company. According to Chen, El Ghoul, Guedhami, \& Wang (2017), foreign institutional stock ownership makes different levels of asymmetric information and agency problems, which can also make a difference in investment behavior. Foreign institutions ownership will mitigate asymmetric agency and information problems by improving transparent corporate and financial governance. Based on the Organization for Economic Co-operation and Development (OECD), companies classified as foreign direct ownership companies are companies that have foreign ownership levels above $10 \%$ or more and have the power and voting rights that can influence company decisions. Figure 1 explains that the average investment value of companies with foreign ownership under $10 \%$ is higher than foreign share ownership above $10 \%$.

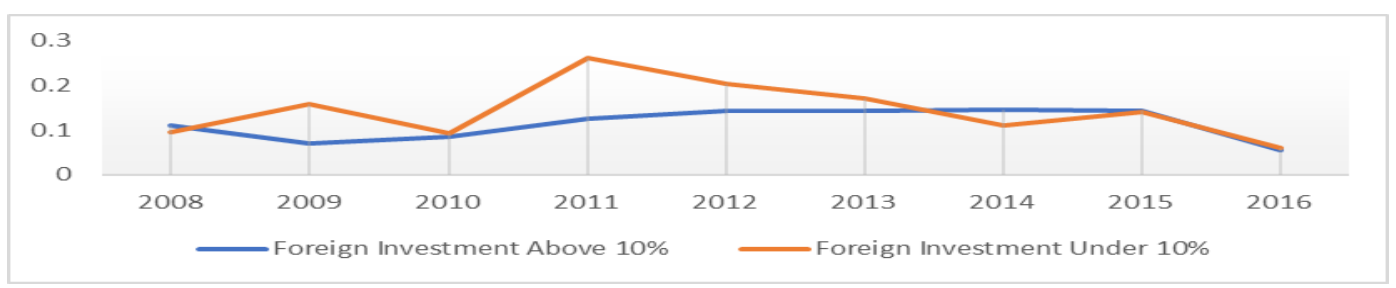

Figure 1 The average of fixed asset investment (ratio of total fixed assets at the beginning of the year) for companies with foreign share ownership above $10 \%$ and below $10 \%$

Source: IDX (2016, Edited) 


\section{Nugroho, Febrianto, Tyasti, \& Kuswibowo \\ The Impact of Foreign Investor Ownership Level on Agency Problems ...}

The average investment data in the above figure shows that investment in companies with foreign ownership more than $10 \%$ has a different pattern and in specific years, has a lower average compared to companies that have a level of foreign share ownership below $10 \%$. This pattern shows an indication that companies with foreign ownership above $10 \%$ are more careful in managing their investments. This argument is in line with studies that argue that foreign investors show higher control over investment decisions. On the other hand, some literature shows empirical evidence that the presence of foreign investors will increase investment, such as the findings of Boubakri, Cosset, and Saffar (2013) which proves that foreign ownership has a positive relationship with corporate investment decision making, with an increase in investment outcomes.

Mutlu, Essen, Peng, and Saleh (2016) and Bruce, Buck, and Main (2005) stated that the application of agency theory is doubtful to be applied to developing companies in the context of non-Anglo Saxon culture and to companies in developing markets (Young, Peng, Ahlstrom, Bruton, \& Jiang, 2008). Sundaramurthy and Lewis (2003) also clarified that in an inefficient market, agency theory would not produce consistent results. Hill and Jones (1992) added that agency theory could function based on the assumption that markets are efficient and can adjust to occurring changes quickly. Currently, Indonesia has shown as an inefficient market (Khanna \& Palepu, 1999). With research results that do not show consistent results, different approaches needed in conducting studies related to investment decisions and their relationship with agency theory in emerging markets such as Indonesia. Furthermore, according to Andrianto and Mirza (2016) Indonesian stock market has been classified as weak form efficiency that they analyzed by using daily stock price data collected from the LQ45 Index, Jakarta Islamic Index (JII), and Kompas 100 Index during the periods of 2013 until 2014. The statistical testing conducted and the results are as follows: the flow of daily stock price is random move, and there is no correlation of stock price movement between the current day and previous days (Andrianto \& Mirza, 2016).

The above description shows that by further examining the effect of the proportion of foreign share ownership on investment decisions in manufacturing companies in the context of non-anglo-Saxon culture and inefficient market conditions in Indonesia, it can provide a new perspective on the application of agency theory in analyzing agency problems in an agency company. The difference between current asset investment and fixed asset investment is that the proportion of current assets can change in the short term in line with changes in the business cycle (Cheatham, 1989).

This study analyzes the effect of the composition of foreign investors on the allocation of corporate funds by investigating capital asset investment and current asset investment interactions. Such analysis has not become the focus of previous researches, which makes this research is vital. This research contributes to the firm's ability to control its own goals. The capital asset investment discussed in this paper refers to longterm investment, while current asset investment refers to short-term investment. 


\section{Literature Review and Hypotheses Development}

Strategic investment decision is described by researchers as important decision (Butler, Davies, Pike, \& Sharp, 1991; Lu \& Heard, 1995; Schoemaker, 1993), and have a significant impact on the organization as a whole (Carr \& Tomkins, 1996) as well as significant potential to improve company's performance (Butler et al., 1991; Carr \& Tomkins, 1996; Cauwenbergh, Durinck, Martens, Laveren, \& Bogaert, 1996). Cossette highlights the ambiguity of the term and notes that "strategic" means "important" or "not secondary" (Cossette, 2004). They do not emphasize the importance of the decision for an organization, yet a more precise definition indicates that strategic decision is a decision regarding the goals, domains, technology, and structure of a company or decision regarding the development of a company through technology market products.

In modern corporations, some efforts involve several stakeholders, such as managers, workers, shareholders, and debt holders, in developing the company together. Different interests in each stakeholder that was potentially causing conflict, and it has to be resolved by the companies. The conflicts between shareholders and managers create agency problems. Agency problems arise when agents work for principals. Agency costs occur when managers do not try to maximize the value of the company, and shareholders incur costs to supervise managers and limit their actions (Brealey, Myers, \& Allen, 2011).

Conflicts of interest between controlling shareholders and minority shareholders have considered as one of the most important corporate governance issues in the Asian stock market. There are essential organizational and behavioral differences between companies in emerging markets and those in developed markets. A top-down approach proposed to analyze how critical institutional forces shape the structure and policies of companies in emerging markets. This approach can be conducted by selectively reviewing previous research in identifying the quality of governance and ownership as a crucial institutional force in shaping corporate finance and governance in developing markets (Fan, Wei, \& Xu, 2011).

Investment sensitivity to free cash flow increased at the level of poor corporate governance. Moreover, according to Francis, Hasan, Song, \& Waisman (2013) states that the sensitivity of free cash flow will escalate whenever the company has weak management. Firms' over-investment is related to current free cash flow, and overinvestment is more likely to occur in firms with positive free cash flows (Chen et al., 2016). This sensitivity reflects the possibility of a lack of supervision on management and companies that have poor governance and difficulties in external funding, so they focus on internal funding. Corporate governance influences the determinants of investment sensitivity for internal cash flow. The level of corporate governance has a positive effect on access to funding. The result of this study supports the agency theory and suggests the existence of problem incentives and monitor costs of managerial actions that can lead to funding friction and affect corporate investment behavior (Francis, et al., 2013). 


\section{Research Method}

This study used a dynamic panel data regression method to explain the effect of foreign investor ownership on the interaction of capital and current asset investment decisions in manufacturing companies listed on the Indonesia Stock Exchange from 2007 to 2018 by considering the institutional ownership. This study used annual data on financial statements of manufacturing companies listed on the Indonesia Stock Exchange (IDX) from 2007 to 2018. The number of samples is taken from 77 manufacturing companies, considering the criteria that the company has never been delisted and used one currency in its financial statements along the periods.

The regression model developed from the previous study (Chen et al., 2017; Nugroho, Firdaus, Andati, \& Irawan, 2018). The model was adopted because it could describe the typical conditions in Indonesia, such as different periods of payment of taxes and dividends that would affect cash flow patterns. The model development is in the form of additional levels of foreign ownership that are more diverse in the range of $0 \%$ to $90 \%$ at $10 \%$ intervals. This research conducted to investigate the pattern of investment behavior related to different levels of foreign investor share ownership in Indonesia manufacturing companies (at low to high concentration of foreign ownership). The basic model is used to determine the effect of the control variable to agency theory. Then the investment model is used to investigate the composition of foreign investors in strengthening or weakening the relationship between capital asset investment and current asset investment. The followings are the regression model used:

Basic Model

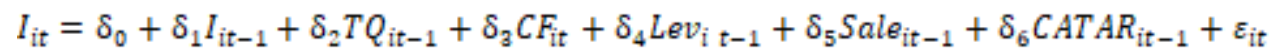

$$
\begin{aligned}
& \delta_{1}>0, \delta_{2}>0, \delta_{2}>0, \delta_{4}<0, \delta_{5}>0, \delta_{6}>0
\end{aligned}
$$

Investment Model

$$
\begin{gathered}
I_{i t}=\delta_{0}+\delta_{1} I_{i t-1}+\delta_{2} T Q_{i t-1}+\delta_{3} C_{i t}+\delta_{4} L_{e v_{i t-1}}+\delta_{5} \text { Sale }_{i t-1}+\delta_{6} \text { CATAR }_{i t-1}+ \\
\delta_{7} D_{\text {own }} \text { it } \\
\text { CATAR }_{i t-1}+\varepsilon_{i t} \\
\delta_{1}>0, \delta_{2}>0, \delta_{3}>0, \delta_{4}<0, \delta_{5}>0, \delta_{6}>0, \delta_{7} \neq 0
\end{gathered}
$$

The variable of capital asset investment $(I)$ is the ratio of capital expenditure to fixed assets at the beginning of the year. The use of capital expenditure on fixed assets at the beginning of the year is essential as a proxy for capital asset investment. We compared the proportion of fixed assets to total assets in order to capture capital asset investment so that it can measure the company's decision to replace assets which its economic life is expired and the addition of fixed assets. Tobin Q (TQ) measured from market value in equity-book value in equity and book value of assets) divided by book value on assets, whereas cash flow (CF) is the operational cash flow divided by the book value of the beginning of the year. Leverage (Lev) is the ratio of total debt to total assets. Sale is the ratio of sales to fixed assets at the beginning of the year. Current asset investment 
(CATAR) is the ratio between current assets and total assets. D_Own is the Dummy variable for foreign ownership. If firm foreign ownership level is higher than a certain level (above $0 \%$ to $90 \%$ ) will be given a value of 1 (one) and 0 (zero) for otherwise.

\section{Result and Discussion}

In order to understand the risk perspective of the use of funds by companies in capital asset investment and current asset investments, it is necessary to analyze the composition of funding sources, especially that comes from external funding (e.i debt). Since debt forces companies to be prudent in the use of existing funds. In the allocation of funding originating from debt, current asset investments certainly have lower consequences compared to capital asset investments because current assets more easily converted into cash.

In Figure 2, we can analyze the ratio of long term liabilities and short term liabilities to total assets. The data of long term liabilities ratio show a declining trend, along with the increase of foreign ownership shares. Long term liabilities continue to decline to the level of foreign ownership concentration at $80 \%$ and then begin to increase. This increase in loans for the long term after $80 \%$ shows that companies are starting to allocate funds from debt for long-term interests (fixed assets). The decline in long-term liabilities expected to affect the company's ability to make long-term investments. Leverage not only reduces the level of investment but also the composition of investments (Hennessy, 2004). The reduction in investment will worsen the condition of long-term assets. If the company has potential growth opportunities, it will reduce the level of leverage and shorten the debt maturity (Myers, 1977).

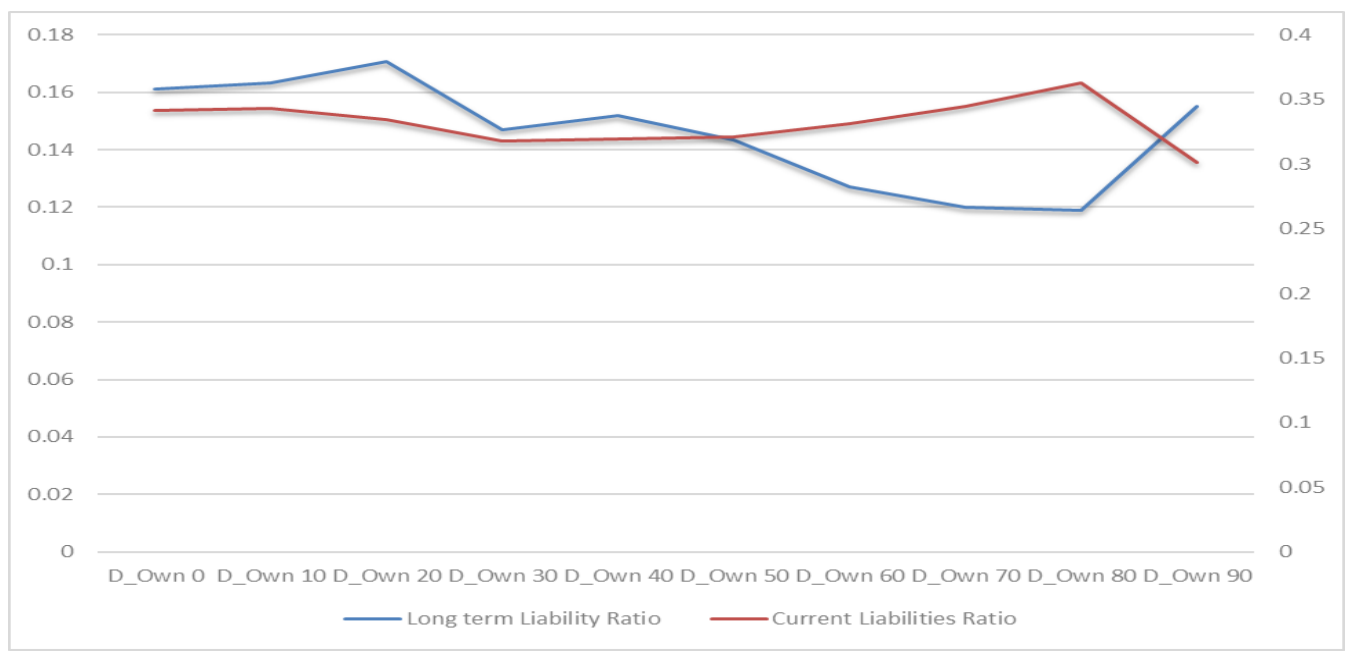

Figure 2 The Ratio of Long Term Liabilities of Manufacturing Companies in Indonesia 


\section{Nugroho, Febrianto, Tyasti, \& Kuswibowo \\ The Impact of Foreign Investor Ownership Level on Agency Problems ...}

Short term liabilities ratio shows an increasing trend. Short-term loans continue to increase until the concentration level of foreign share ownership reaches $80 \%$. These indicate that the company is investing in a short term purpose i.g company operational financing. Indonesia manufacturing companies development is one factor for foreign investors to maximize company value through the addition of machinery to the expansion of company buildings. Foreign investors tend to improve the condition of the company before investing (in the proportion of long term liabilities). Correspondingly, Nugroho \& Suk (2019) stated that developing countries tend to choose short-term debt funding rather than long-term debt to reduce problems.

In the ratio movement of long term liabilities and short term liabilities, there is a similar pattern in the composition of ownership above $0 \%$ to above $40 \%$, but after the composition of ownership above $50 \%$ to above $80 \%$, the pattern tends to be the opposite. This trend shows that in general, companies with a composition of foreign ownership above $50 \%$ to above $80 \%$ increase the composition of short-term debt and reduce the composition of long-term debt; this indicates that the investor tends to demand the management to improve their short-term performance.

From these findings, it is necessary to learn more about whether the behavior of the composition of short term and long term debt affected investment decisions and how the interaction of capital and current investment decisions. The problem of information asymmetry among management, financial institutions, and controlling shareholders will cause agency problems in manufacturing companies, which will affect the company's investment decisions. Several studies explain that capital investment decisions influenced by several important factors, including the investment in the previous year (McGrattan, 1999), cash flow (Chen et al., 2016; Jiang, Kim, Nofsinger, \& Zhu, 2015) sales (Aguerrevere, 2009), and leverage (Firth, Malatesta, Xin, \& Xu, 2012).

Table 1 shows the results that provide empirical evidence of agency problems, which are shown in the negative relationship between leverage from the previous period and capital investment in period $t$, showing that increasing leverage will make management more careful in making capital investments in the following year. The empirical evidence is following Jiang et al (2015), Anwar and Sun (2015) and Aivazian, Ge, and Qiu (2005). However, what happens behind this negative relationship must be explored further by looking at the relationship with the company's decision in current investment because the indication in figure 2 shows there is an increase in short-term liabilities as of the composition of foreign shareholders increases at a certain proportion.

Baum, Schäfer, \& Talavera (2006) and Fazzari and Petersen (1993) show that corporate profitability will increase when using short-term funding, where companies have a high dependency on short-term debt related to company profits. The company uses short term liabilities as working capital to improve short-term financial performance. On the other hand, if a company adopts an aggressive approach to managing short-term liabilities, investors will add value to these companies (Afza \& Nazir, 2007). The level of aggressiveness of the working capital policy only helps create shareholder wealth by improving the market performance of the company. 
Table 1 Estimation Result of Model 1

\begin{tabular}{ll}
\hline Variable & Base Model \\
\hline Investment $_{\mathrm{it}-1}$ & $.0227393^{* * *}$ \\
$\mathrm{CF}_{\mathrm{it}}$ & $.2202251^{* * *}$ \\
$\mathrm{TQ}_{\mathrm{it}-1}$ & .0025279 \\
Sales $_{\mathrm{it}-1}$ & $.0402098^{* * *}$ \\
Lev $_{\mathrm{it}-1}$ & $-.2666079 * *$ \\
CATAR $_{\mathrm{it}-1}$ & $.546892^{* * *}$ \\
Cons & $-.362039 * * *$ \\
Sargan (Prob) & .2364 \\
Arellano bond M1 (Prob) & .0056 \\
\hline Arellano bond M2 (Prob) & .4664 \\
\hline
\end{tabular}

Note: Symbol $* * *, * * *$ indicates significance on $10 \%, 5 \%, 1 \%$

The estimation results in Table 1 show that the Current Assets to Total Assets Ratio (CATAR) variable has a negative influence on the next period of long term investment decisions, following the notion that when investing in the short-term, the company sacrifices capital investment decisions in the next period. Current assets to total assets ratio (CATAR) reflect the availability of cash, receivables, and inventory, which are the most liquid current assets compared to the overall assets owned by the company (Saputri, Sulastri, \& Bakar, 2016). The existence of liquid assets can be used at any time to finance the company's operational needs to generate profits (Syamsuddin, 2007).

When the company has funds and seeks to increase its value, the company will have two choices in utilizing the funds. The first alternative is to increase the proportion of current investment and decrease the proportion of capital investment, or vice versa. The second alternative is to maintain the proportion of current and capital investment. Given the relationship between empirical evidence and positive relationships, the increasing CATAR in Indonesian manufacturing companies affected capital investment and a significant positive influence on the investment. This positive influence happened likely because companies are trying to take advantage of opportunities that exist in the market to increase their competitiveness with optimizing their operations.

Therefore, by investigating the regression coefficient of the interaction variable between CATAR and foreign share ownership indicated by the interaction variable CATAR*Down in Table 2, there is an interval of foreign ownership in the range of ownership concentration from above $0 \%$ to $40 \%$ which shows an increasing trend on the variable interaction coefficient, but companies with a foreign ownership to level above $70 \%$ trend on coefficient value are forming a $\mathrm{U}$-shape curve, and when the concentration level reaches above $80 \%$. The pattern shows a behavioral change of companies in managing their capital and current investments on different levels of foreign ownership.

At concentration level intervals of share ownership by foreign investors above $0 \%$ to above $40 \%$, there are still manufacturing companies in the sample of companies whose foreign investor positions are minority shareholders. At this interval of a concentration level of share ownership by foreign investors, a positive trend obtained significantly at 
the level of share ownership by foreign investors to above $40 \%$. This result shows that the existence of national companies where foreign investors are minority shareholders influences the regression coefficient. The positive trend of the coefficient of interaction variable is an indication that there are companies that tend to use their funds to make capital investments, and they do not just focus on current investments.

Table 2 Estimation Result of Model 2

\begin{tabular}{|c|c|c|c|c|c|}
\hline Variable & $>0 \%$ & $>10 \%$ & $>20 \%$ & $>30 \%$ & $>40 \%$ \\
\hline Investment $_{\text {it-1 }}$ & $.02346743 * * *$ & $.02340757 * * *$ & $.0232598 * * *$ & $.02184833^{* * *}$ & $.023435 * * *$ \\
\hline $\mathrm{CF}_{\text {it }}$ & $.22229066 * * *$ & $.22176747^{* * *}$ & $.22270476 * * *$ & $.2175334 * * *$ & $.19245294 * * *$ \\
\hline $\mathrm{TQ}_{\mathrm{it}-1}$ & .00129024 & .00241556 & 0.00241396 & 0.00271918 & -0.00014911 \\
\hline Sales $_{\mathrm{it}-1}$ & $.03962453^{* * *}$ & $.04078623^{* * *}$ & $.03958039 * * *$ & $.03907549 * * *$ & $.04172388 * * *$ \\
\hline $\operatorname{Lev}_{\text {it-1 }}$ & $-.25291732 * * *$ & $-.26565004^{* * *}$ & $-.26833568 * * *$ & $-.25813424 * * *$ & $-.25240055^{* * *}$ \\
\hline CATAR $_{\mathrm{it}-1}$ & $.98666624^{* * *}$ & $.89017776^{* * *}$ & $.93075041^{* * *}$ & $.70025497^{* * *}$ & $.25680714^{* * *}$ \\
\hline Down $_{\text {it }}(>0 \%)$ & $.36497211 * * *$ & & & & \\
\hline CATAR $_{\text {it- } 1} *$ Down $_{\text {it }}(>0 \%)$ & $-.55877944 * * *$ & & & & \\
\hline Down $_{\text {it }}(>10 \%)$ & & $.32071321 * * *$ & & & \\
\hline CATAR $_{\text {it-1 }} *$ Down $_{\text {it }}(>10 \%)$ & & $-.46068016^{* * *}$ & & & \\
\hline Down $_{\text {it }}(>20 \%)$ & & & $.36927229 * * *$ & & \\
\hline CATAR $_{\text {it-1 }} *$ Down $_{\text {it }}(>20 \%)$ & & & $-.51497309 * * *$ & & \\
\hline Down $_{\text {it }}(>30 \%)$ & & & & $.19689898 * * *$ & \\
\hline CATAR $_{\text {it-1 }} *$ Down $_{\text {it }}(>30 \%)$ & & & & $-.19072901 * * *$ & \\
\hline Down $_{\text {it }}(>40 \%)$ & & & & & $-.04110767 * * *$ \\
\hline CATAR $_{\mathrm{it}-1} *$ Down $_{\mathrm{it}}(>40 \%)$ & & & & & $.42966632 * * *$ \\
\hline _cons & $-.63854524 * * *$ & $-.59702588 * * *$ & $-.62676378 * * *$ & $-.49959053^{* * *}$ & $-.28371396 * * *$ \\
\hline Sargan (Prob) & .4212 & 0.3950 & 0.3134 & 0.3267 & 0.3661 \\
\hline Arellano bond M1 (prob) & 0.0060 & 0.0058 & 0.0059 & 0.0060 & 0.0058 \\
\hline Arellano bond M2 (prob) & 0.9736 & 0.9895 & 0.9397 & 0.8841 & 0.8264 \\
\hline Variabel & $>50 \%$ & $>60 \%$ & $>70 \%$ & $>80 \%$ & $>90 \%$ \\
\hline Investment $_{\text {it-1 }}$ & $.02527776 * * *$ & $.01930678^{* * *}$ & $.02104901 * * *$ & $.02250607^{* * *}$ & $.02252073^{* * *}$ \\
\hline $\mathrm{CF}_{\mathrm{it}}$ & $.22358517^{* * *}$ & $.22490981 * * *$ & $.22597407^{* * *}$ & $.2201802 * * *$ & $.22241594^{* * *}$ \\
\hline $\mathrm{TQ}_{\mathrm{it}-1}$ & $.00813905^{* * *}$ & $.00612444 * * *$ & $.00438884^{*}$ & 0.00230673 & 0.00162304 \\
\hline Sales $_{i t-1}$ & $.03078403^{* * *}$ & $.03346844^{* * *}$ & $.03657822^{* * *}$ & $.04092449 * * *$ & $.0404373 * * *$ \\
\hline $\operatorname{Lev}_{\mathrm{it}-1}$ & $-.26919246 * * *$ & $-.27794091 * * *$ & $-.27185514^{* * *}$ & $-.26778695^{* * *}$ & $-.2687477^{* * *}$ \\
\hline CATAR $_{\text {it-1 }}$ & $1.5001893^{* * *}$ & $1.1838165^{* * *}$ & $.90072606 * * *$ & $.50882272 * * *$ & $.56015405^{* * *}$ \\
\hline Down $_{\text {it }}(>50 \%)$ & $.68043736 * * *$ & & & & \\
\hline CATAR $_{\text {it- }} *$ Down $_{\text {it }}(>50 \%)$ & $-1.3147349 * * *$ & & & & \\
\hline Down $_{\text {it }}(>60 \%)$ & & $.62809735^{* * *}$ & & & \\
\hline CATAR $_{\mathrm{it}-1} *$ Down $_{\mathrm{it}}(>60 \%)$ & & $-1.2429983 * * *$ & & & \\
\hline Down $_{\text {it }}(>70 \%)$ & & & $.49011184^{* * *}$ & & \\
\hline CATAR $_{\text {it }-1} *$ Down $_{\text {it }}(>70 \%)$ & & & $-.89594962 * * *$ & & \\
\hline Down $_{\text {it }}(>80 \%)$ & & & & -0.0409141 & \\
\hline CATAR $_{\text {it- } 1} *$ Down $_{\text {it }}(>80 \%)$ & & & & .08038831 & \\
\hline Down $_{\text {it }}(>90 \%)$ & & & & & $.12418574^{* * *}$ \\
\hline CATAR $_{\mathrm{it}-1}{ }^{*}$ Down $_{\mathrm{it}}(>90 \%)$ & & & & & $-.29191583 * * *$ \\
\hline _cons & $-.87003027 * * *$ & $-.69432198 * * *$ & $-.54927494 * * *$ & $-.33244891 * * *$ & $-.35663039 * * *$ \\
\hline Sargan (Prob) & 0.2763 & 0.3708 & 0.3309 & 0.3747 & 0.3145 \\
\hline Arellano bond M1 (prob) & 0.0055 & 0.0058 & 0.0055 & 0.0055 & 0.0056 \\
\hline Arellano bond M2 (prob) & 0.9492 & 0.8507 & 0.9530 & 0.9924 & 0.9850 \\
\hline
\end{tabular}

Note: Symbol *, **,*** indicates significance on standard $10 \%, 5 \%, 1 \%$

Furthermore, at concentration intervals of share ownership by foreigners above $50 \%$ to above $70 \%$, a pattern change occurs in the regression coefficient. At intervals of 
concentration levels of share ownership by foreign investors above $50 \%$ to above $70 \%$, foreign investors become dominant shareholders and have the power to control company policy.

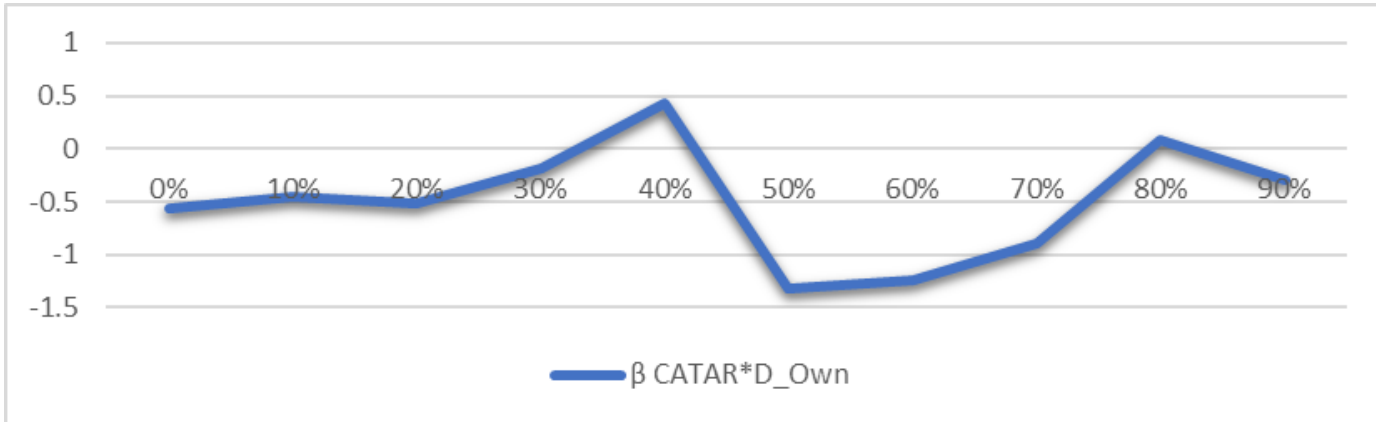

Figure 3 Compilation on Estimated Results of Dynamic Panel Data Models at All Intervals of Foreign Ownership Concentration

In Figure 3, the changing trend on the coefficient occurs at the level of concentration of share ownership by foreign investors above $50 \%$ to above $70 \%$. It reached the lowest negative point at the concentration level of share ownership by foreign investors above $50 \%$. However, this pattern shows a positive trend pattern to the above $80 \%$ level. These results indicate agency problems at a concentration level of foreign share ownership above $50 \%$ to above $70 \%$, which are higher than at other levels of ownership. This agency problem encourages foreign investors to increase control over management by focusing on current investments, as this situation forces management to improve the company's current performance. Meanwhile, at the concentration level of foreign shareholding above $80 \%$, foreign companies will act as dominant company owners, and the positive relationship of the interaction variables is an indication that there are companies at the intervals of foreign share ownership that have a tendency to use funds owned to make capital investments. They do not only focus on making current investments. This result supported by previous data in Figure 2, where at concentration level intervals of share ownership by foreign investors above $80 \%$ to above $90 \%$, the average long-term debt returns to increase.

From the results, this study provides empirical evidence that that agency problem will also affect the behavior of capital investment and current investment of the company. Foreign investors use current investment mechanisms to exercise control over the company's management to force management to deliver current performance results. It also provides empirical evidence that agency problems can cause companies to limit capital investment.

\section{Conclusion}

The different levels of share ownership by foreign investors show different investment decisions. This argument is supported by empirical evidence that demonstrated by the 
effect of control over investment at a certain level. When the proportion of foreign share ownership ranges from above $50 \%$ to above $70 \%$, investment decisions will focus more on short-term investments. Empirical evidence showed that when foreign investors begin to become the dominant group of shareholders, they try to control the management of the company by focusing more on current investments. The phenomenon occurred along with the increasing data on average capital loans. These conditions indicate that the level of ownership of foreign investors will be affected by control over management in decisions to invest in the short term or long term investment. Another control mechanism is needed in the company to prevent overinvestment, but also prevents the company from under-investment and losing the opportunity that exists in the market. This research has not considered the company's risk characteristics related to the type of industry, for further research development it is necessary to consider the company's risk characteristics to enhance the analysis

\section{References}

Afza, T., \& Nazir, M. (2007). Is it better to be aggressive or conservative in managing working capital. Journal of Quality and Technology Management. 3(2), 11-21. Retrieved from https://www.researchgate.net/publication/259828572 Is it Better to be Aggressi ve or Conservative in Managing Working Capital

Aguerrevere, F. L. (2009). Real options, product market competition, and asset returns. Journal of Finance, 64(2), 957-983. https:// doi.org/10.1111/j.1540-6261.2009.01454.x

Aivazian, V. A., Ge, Y., \& Qiu, J. (2005). The impact of leverage on firm investment: Canadian evidence. Journal of Corporate Finance, 11, 277-291. https://doi.org/10.1016/S0929-1199(03)00062-2

Andrianto, Y., \& Mirza, A. R. (2016). A Testing of Efficient Markets Hypothesis in Indonesia Stock Market. Procedia - Social and Behavioral Sciences, (219), 99-103. https://doi.org/10.1016/j.sbspro.2016.04.048

Anwar, S., \& Sun, S. (2015). Can the presence of foreign investment affect the capital structure of domestic firms? Journal of Corporate Finance. 30, 32-43. https://doi.org/10.1016/j.jcorpfin.2014.11.003

Baum, C. F., Schäfer, D., \& Talavera, O. (2006). The Effects of Short-Term Liabilities on Profitability: The Case of Germany. Working Paper. https://doi.org/10.2139/ssm. 967260

Boubakri, N., Cosset, J. C., \& Saffar, W. (2013). The role of state and foreign owners in corporate risk-taking: Evidence from privatization. Journal of Financial Economics, 108, 641-658. https://doi.org/10.1016/i.jfineco.2012.12.007

Brealey, R., Myers, S., \& Allen, F. (2011). Principles of Corporate Finance. Singapore: McgrawHill Education (Asia).

Bruce, A., Buck, T., \& Main, B. G. M. (2005). Top executive remuneration: A view from Europe. Journal of Management Studies, 42(7), 1493-1506. https://doi.org/10.1111/j.1467-6486.2005.00553.x

Butler, R., Davies, L., Pike, R., \& Sharp, J. (1991). Strategic Investment Decision - Making: Complexities, Politics and Processes. Journal of Management Studies, 28(4), $395-415$. https://doi.org/10.1111/j.1467-6486.1991.tb00288.x 


\section{Nugroho, Febrianto, Tyasti, \& Kuswibowo \\ The Impact of Foreign Investor Ownership Level on Agency Problems ...}

Carr, C., \& Tomkins, C. (1996). Strategic investment decisions: The importance of SCM. A comparative analysis of 51 case studies in U.K., U.S. and German companies. Management Accounting Research, 7(2), 199-217. https://doi.org/10.1006/mare.1996.0012

Cheatham, C. (1989). Economizing On Cash Investment In Current Assets. Managerial Finance. 15(6), 20-26. https://doi.org/10.1108/eb013630

Chen, R., El Ghoul, S., Guedhami, O., \& Wang, H. (2017). Do state and foreign ownership affect investment efficiency? Evidence from privatizations. Journal of Corporate Finance, 42, 408-421. https://doi.org/10.1016/j.jcorpfin.2014.09.001

Chen, X., Sun, Y., \& Xu, X. (2016). Free cash flow, over-investment and corporate governance in China. Pacific Basin Finance Journal, 37, 81-103. https://doi.org/10.1016/i.pacfin.2015.06.003

Cossette, P. (2004). L'organisation Une perspective cognitiviste. Laval: Les Presses de l'Université Laval.

Eisenhardt, K. M. (1989). Agency Theory: An Assessment and Review. Academy of Management Review, 14(1), 57-74. https://doi.org/10.5465/amr.1989.4279003

Fan, J. P. H., Wei, K. C. J., \& Xu, X. (2011). Corporate finance and governance in emerging markets: A selective review and an agenda for future research. Journal of Corporate Finance, 207-214. https://doi.org/10.1016/j.jcorpfin.2010.12.001

Fazzari, S. M., \& Petersen, B. C. (1993). Working Capital and Fixed Investment: New Evidence on Financing Constraints. The RAND Journal of Economics, 24(3), 328-342. https://doi.org/10.2307/2555961

Firth, M., Malatesta, P. H., Xin, Q., \& Xu, L. (2012). Corporate investment, government control, and financing channels: Evidence from China's Listed Companies. Journal of Corporate Finance, 18(3), 433-450. https://doi.org/10.1016/i.jcorpfin.2012.01.004

Francis, B., Hasan, I., Song, L., \& Waisman, M. (2013). Corporate governance and investment-cash flow sensitivity: Evidence from emerging markets. Emerging Markets Review. 15, 57-71. https://doi.org/10.1016/i.ememar.2012.08.002

Guariglia, A., \& Yang, J. (2016). A balancing act: Managing financial constraints and agency costs to minimize investment inefficiency in the Chinese market. Journal of Corporate Finance. 36, 111-130. https://doi.org/10.1016/j.jcorpfin.2015.10.006

Haaskjold, H., Andersen, B., Lædre, O., \& Aarseth, W. (2019). Factors affecting transaction costs and collaboration in projects. International Journal of Managing Projects in Business. 13(1), 197-230. https://doi.org/10.1108/IJMPB-09-2018-0197

Hennessy, C. A. (2004). Tobin's Q, debt overhang, and investment. Journal of Finance, 59(4), 1717-1742. https://doi.org/10.1111/j.1540-6261.2004.00677.x

Hill, C. W. L., \& Jones, T. M. (1992). Stakeholder - Agency Theory. Journal of Management Studies, 29(2), 131-154. https://doi.org/10.1111/j.1467-6486.1992.tb00657.x

Jiang, F., Kim, K. A., Nofsinger, J. R., \& Zhu, B. (2015). Product market competition and corporate investment: Evidence from China. Journal of Corporate Finance, 35, 196-210. https://doi.org/10.1016/i.jcorpfin.2015.09.004

Karuna, C. (2007). Industry product market competition and managerial incentives. Journal of Accounting and Economics, 43(2-3), 275-297. https://doi.org/10.1016/j.jacceco.2007.02.004

Khanna, T., \& Palepu, K. (1999). Emerging Market Business Groups, Foreign Investors, and Corporate Governance. In Nber Working Paper Series. Retrieved from http://www.nber.org/papers/w6955

Laksmana, I., \& Yang, Y. W. (2015). Product market competition and corporate investment decisions. Review of Accounting and Finance, 14(2), 128-148.

https://doi.org/10.1108/RAF-11-2013-0123 
Lu, Y., \& Heard, R. (1995). Socialized Economic Action: A Comparison of Strategic Investment Decisions in China and Britain. Organization Studies, 16(3), 395-424. https://doi.org/10.1177/017084069501600302

McGrattan, E. (1999). Maintenance and Repair: Too Big to Ignore. Federal Reserve Bank of Minneapolis Quarterly Review, 23(4), 2-13. https://doi.org/10.21034/qr.2341

Michalski, G. (2008). Operational risk in current assets investment decisions: Portfolio management approach in accounts receivable. Agricultural Economics, 54(1), 12-19. https://doi.org/10.17221/254-agricecon

Mutlu, C., Essen, V., Peng, M., \& Saleh, S. (2016). Agency Theory and Corporate Governance in China: A Meta-Analysis. Journal of Management Studies. 55(6), 943-979. https://doi.org/10.1111/joms.12331

Myers, S. C. (1977). Determinants of corporate borrowing. Journal of Financial Economics, 5, 147-175. https://doi.org/10.1016/0304-405X(77)90015-0

Nugroho, A. C., Firdaus, M., Andati, T., \& Irawan, T. (2018). Does Foreign Ownership Affect Investment Decisions of Manufacturing Companies in Indonesia? Asian Joumal of Applied Sciences, 6(6), 468-474. https://doi.org/10.24203/ajas.v6i6.5546

Nugroho, V., \& Suk, K. (2019). Relationship between leverage, maturity, and investment decision: evidence from emerging markets. Organizations and Market in Emerging Economics Journal, 10(1), 147-164. https://doi.org/10.15388/omee.2019.10.00008

Saputri, A. Y., Sulastri, \& Bakar, S. W. (2016). Pengaruh Keputusan Investasi Terhadap Nilai Perusahaan Pada Perusahaan Sektor Manufaktur Sub Sektor Makanan Dan Minuman Yang Terdaftar Di Bursa Efek Indonesia. Jurnal Ilmiah Manajemen Bisnis Dan Terapan, 13(2), 113-128. Retrieved from https://ejournal.unsri.ac.id/index.php/jembatan/article/view/4025

Schoemaker, P. J. H. (1993). Strategic Decisions in Organizations: Rational and Behavioral Views. Journal of Management Studies, 30(1), 106-129. https://doi.org/10.1111/j.14676486.1993.tb00297.x

Sundaramurthy, C., \& Lewis, M. (2003). Control and collaboration: Paradoxes of governance. Academy of Management Review, 28(3), 397-415. https://doi.org/10.5465/AMR.2003.10196737

Syamsuddin, L. (2007). Manajemen kenangan perusahaan: konsep aplikasi dalam: perencanaan, pengawasan, dan pengambilan keputusan. Manajemen Keuangan. Jakarta: PT. Raja Grafindo Persada.

Van Cauwenbergh, A., Durinck, E., Martens, R., Laveren, E., \& Bogaert, I. (1996). On the role and function of formal analysis in strategic investment decision processes: Results from an empirical study in Belgium. Management Accounting Research, 7(2), 169-184. https://doi.org/10.1006/mare.1996.0010

Young, M. N., Peng, M. W., Ahlstrom, D., Bruton, G. D., \& Jiang, Y. (2008). Corporate governance in emerging economies: A review of the principal-principal perspective: Review paper. Journal of Management Studies, 45(1), 196-220. https://doi.org/10.1111/i.1467-6486.2007.00752.x 